\title{
Spreading across Boundaries: Coronavirus and Computer Virus
}

\author{
Alan Garfield* \\ Professor and Chair Digital Art \& Design Department University of Dubuque Dubuque, Iowa USA \\ *Corresponding Author: Alan Garfield, Professor and Chair Digital Art \& Design Department \\ University of Dubuque Dubuque, Iowa USA

\begin{abstract}
With the new coronavirus spreading from person to person (including from people without symptoms), reaching four continents and every island nation, and traveling faster than SARS, driving it out of existence is looking increasingly unlikely. Actually, the same might be (and has been) said about the state of computer viruses and malware. Everything's going to be different, on the other side of this - whether this is our body health or computer health. What, really, are the similarities and differences between the effects of that one word - virus - on human biological systems and our digital computing systems? This essay addresses issues that we should be aware of.
\end{abstract}

\section{INTRODUCTION}

Do you remember seeing the landing of the space module on the Moon on July 20, 1969? Or perhaps, given the relative youth of this audience, maybe you read about it or saw it on YouTube. Let me review the Lunar Landing Mission with you just for a moment. It was Apollo 11 - the first manned mission to land on the Moon. If things were to go according to plan, the astronauts were going to do a little shopping and return. (And they did.) But before those first steps by Neil Armstrong and Buzz Aldrin, we all saw this.

That's when it hit me. This was anthropomorphism in the space race. Sure, we attribute human traits to non-human entities, like dogs, cats, walking/talking/smiling paper clips, for instance. But now I saw how the technology of the Lunar Excursion Module was designed. It was based on my foot, lower leg (fibula and tibia), knee (medial/lateral condyle and patella) and my upper leg (femur) plus all the muscles and vessels holding them together. The LEM was acting like my body does when I jump down from a chair to the floor. My leg doesn't cave or break, it bends to absorb the shock (those g's). So, when the LEM sensors (on the bottom of the pods) touched the Moon and power was cut and the module landed, it landed softly and safely. The LEM, metal parts, was designed to act like my body.

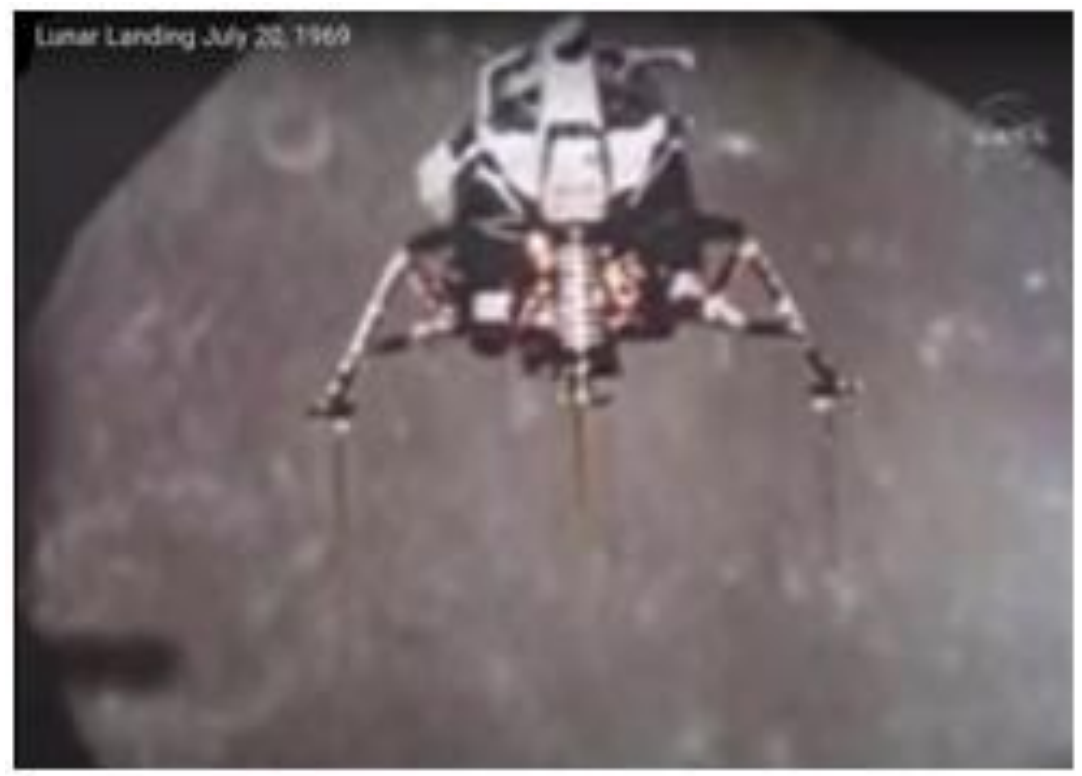

Figure1. https://www.nasa.gov/content/former-astronauts-recall-historic-first-moon-landing 


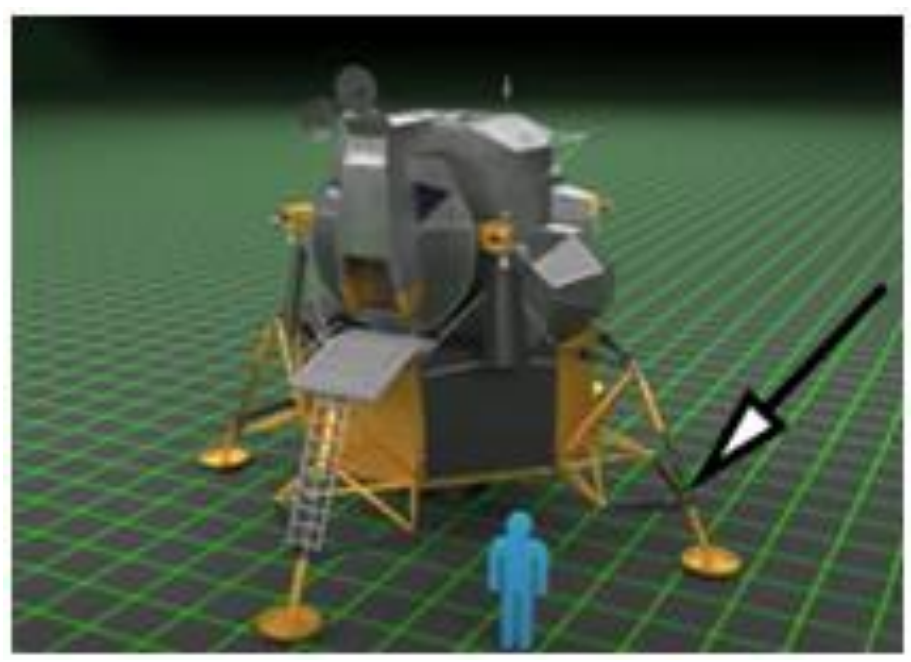

Figure2. Computer generated landing pod. Arrow pointing at bendable arm.

If God made man is His image, we make stuff - all kinds of stuff - in ours. We design and engineer based upon how our body acts and reacts. So when computer viruses were first engineered, they emulated the way viruses act in our body, taking advantage of vulnerabilities. And they still do.

Case in point, of course, is COVID-19. And because of COVID-19, everyone has had a forced primer on Virology 101 and not just the basics of viruses but how a virus unfolds. And this goes both ways. Now it's so much easier to talk about what medical research is finding because of our reliance on computer terms and technology.

So how do viruses work, viruses like the novel coronavirus (whose accurate name is SARS-CoV-2, severe acute respiratory syndrome, corona virus, version 2.

\section{Life cycle of SARS-CoV-2 coronavirus, a single-stranded (+) RNA virus}

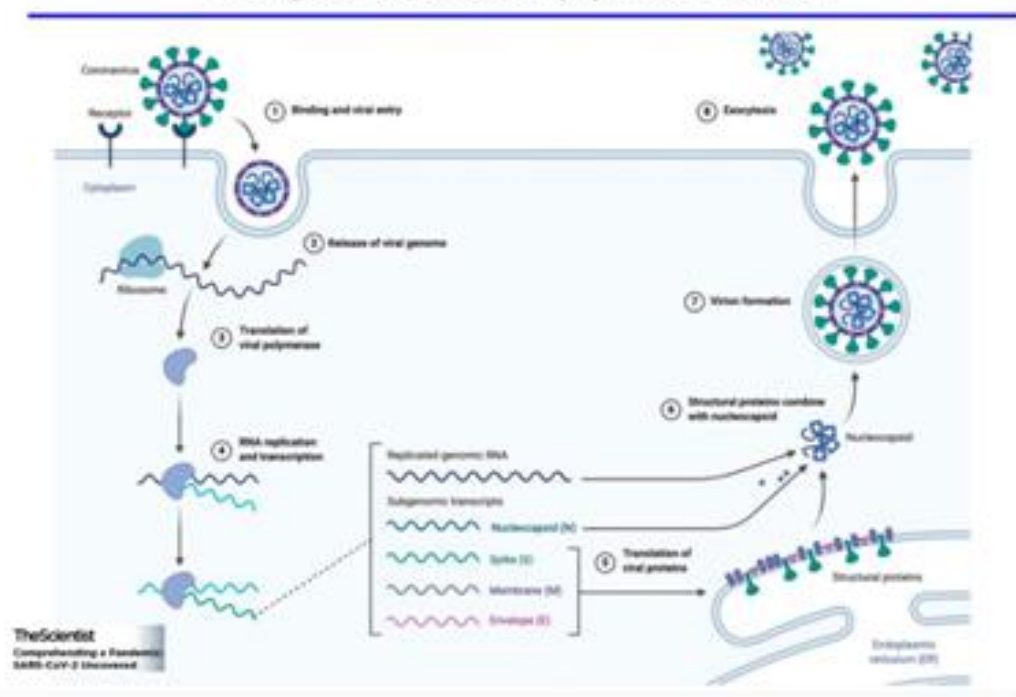

Figure3. From "Comprehending a Pandemic: SARS-CoV-2 Uncovered" https://www.themscientist.com/spons ored-webinars/sars-cov-2-webinar-67527

Viruses are very simple structures, made of up of just a few very basic biological molecules. They have some genetic material, and that encodes their various proteins that they need to be a virus, to make a structure of a virus. That genetic material can either be DNA or RNA. And apart from the genetic material, all they really have is then a coat of protein and lipids surrounding the genetic material. They're very simple and very small particles.

And they're incredibly abundant in nature, so for example in one drop of sea water there's probably about 10 million viral particles. So really, really abundant. And new ones are being discovered all the time (there are lots of viruses we still don't know about that exist out there). 
Both DNA and RNA are genetic material - in other words, they have the ability to contain information. In our bodies, RNA is the molecule that brings the information from the DNA to the machines in our cells that make proteins. You can actually encode information either in DNA or RNA. In this case, the SARS-CoV-2 - is an RNA virus.

The sequencing of RNA defines molecular biology today the way that DNA did twenty years ago. Our DNA is shared by every cell in our body, and yet the difference in appearance and function is caused by DNA strands which have been changed into molecules of single-stranded RNA. And these RNA strands are the blueprints for proteins, the molecular machines that do most of a cell's work. Complex and very low-level.

By comparison,colds and flus are diseases that are caused by specific viruses, milder coronaviruses, that cause the common cold in humans. Flu is caused by the influenza virus, probably originating in ducks or birds and jumping to humans a long time ago. Measles is a very common viral infection. So, too, Herpes, Hepatitis C, and the more exotic ones like the Ebola and Zika virus.

Viruses have to get inside our bodies because they need a cell to be able to replicate and to produce more virus particles, so viruses are a bit like molecular parasites. You might remember from your biology in school that a parasite is an organism that co-exists with another organism, and if it's an obligate parasite it means it needs that other organisms to survive. And viruses need a cell to survive in. Once they're inside the body, they have to get inside a cell, and for some viruses that's very easy because they can just be sucked in by the cell in different ways.

Viruses have to bind to a very specific receptor on a cell. This in fact is really interesting because this then defines why some viruses can infect certain people. In the case of SARS-CoV-2, there's a protein on human cells called ACE2 that it binds to. That's the receptor it uses to get inside cells, so if SARSCoV-2 was not able to bind to ACE2 on the surface of our cells it wouldn't be a problem at all. Even in terms of a whole population, one reason that some people might be more susceptible to this virus than others, for example older people versus children, might have to do with how much of that receptor they actually express on their cells.

\section{How do we treat SARS-CoV-2 and prevent its spread?}

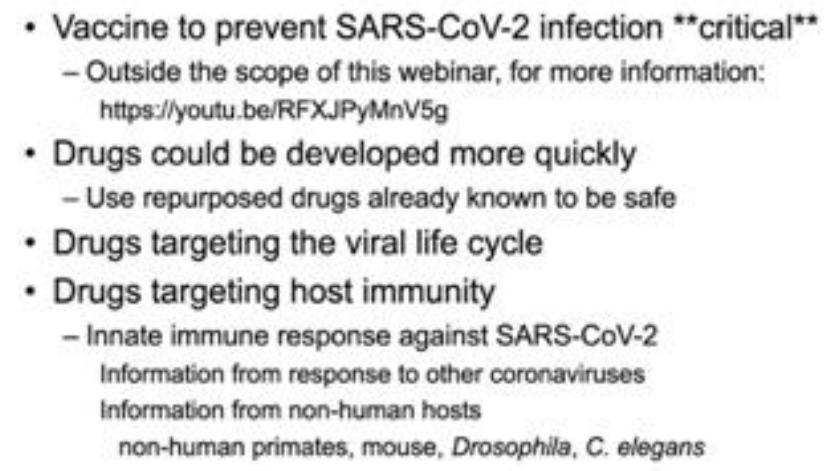

Once the virus sticks to the outside of a cell, using one of these receptors, it then gets taken inside the cell, and then what it does is it hijacks the cell's machinery and uses the cell's machinery to replicate itself. You see, our cells have all sorts of proteins inside them that are used to replicate our own cells, and to produce new cells, and the virus hijacks all that machinery and uses it. The term that is often used here is that there can be "viral factories" in the inside of our cells. And if viral factories get produced, then the virus can very rapidly produce multiple copies of its genetic information and can assemble new viral capsids, as they're called. What next happens is a dizzying array. Viral particles pop out of infected cells and in a matter of days, one cell can actually produce millions of viral particles.

Now this makes it seem that viruses are alive, because they need to be in a body, or if they need a host as such, could we consider them to be alive? Actually, there are loads of articles written over the years discussing the science and even the philosophy behind this. How do we define life, and basically, are viruses actually alive? I'm not going to deal with it all here, but I like what Edward 
Rybicki (1990, U of Cape Town) said: “viruses are 'organisms at the edge of life.' They're sort of alive. Some researchers define life as the ability to reproduce oneself, but then viruses can only reproduce if they're inside a host cell. So the host cell could be a human cell, but they need to be inside a cell to replicate. In the end, it depends on how you define life, but personally, I like the idea that viruses are 'organisms at the edge of life'.

And while both viruses and bacteria cause disease (we call them pathogens), how the body fights them can be quite different. And one big difference is size. On average (and viruses vary a lot), a virus can easily be one hundredth the size of a bacterial cell.

Another difference between viruses and bacteria is cell structure; I've already described how viruses are very simple - they've just got protein, lipids, and genetic material. Bacteria are much more complicated and much harder to understand actually. But this discussion is not about bacteria.

How is SARS-Cov-2 stopped? Antibodies or vaccines.

What are antibodies? They're proteins first of all. They're a key type of weapon that our immune system has in order to fight intruders, and they bind very specifically and very tightly to their target molecule. The target molecule they bind to is usually a foreign molecule, so our immune system is able to discriminate between molecules it sees all the time, normal molecules that circulate in our body, and molecules that shouldn't be there - foreign invaders such as viruses.

Our immune system can generate antibodies to foreign materials and that's why if you have certain antibodies in your system it's actually a sign that you've been exposed to those foreign materials. How do antibodies work? They bind. They bind very tightly to their target molecules on viruses. The antibodies that are most interesting currently are called neutralizing antibodies, called that because they can neutralize the pathogen or the invader.

Antibodies can be generated in lots of different ways. They can come from natural immunity, implying that you've been exposed to SARS-CoV-2. They can also come from being exposed to a very similar virus - like MERS (Middle East Respiratory Syndrome 2012 SA) or actually SARS (Severe Acute Respiratory Syndrome 2003 China). If you've been exposed to those viruses in the past, your body has made antibodies, measurable antibodies, that may/or may not be able to neutralize this virus.

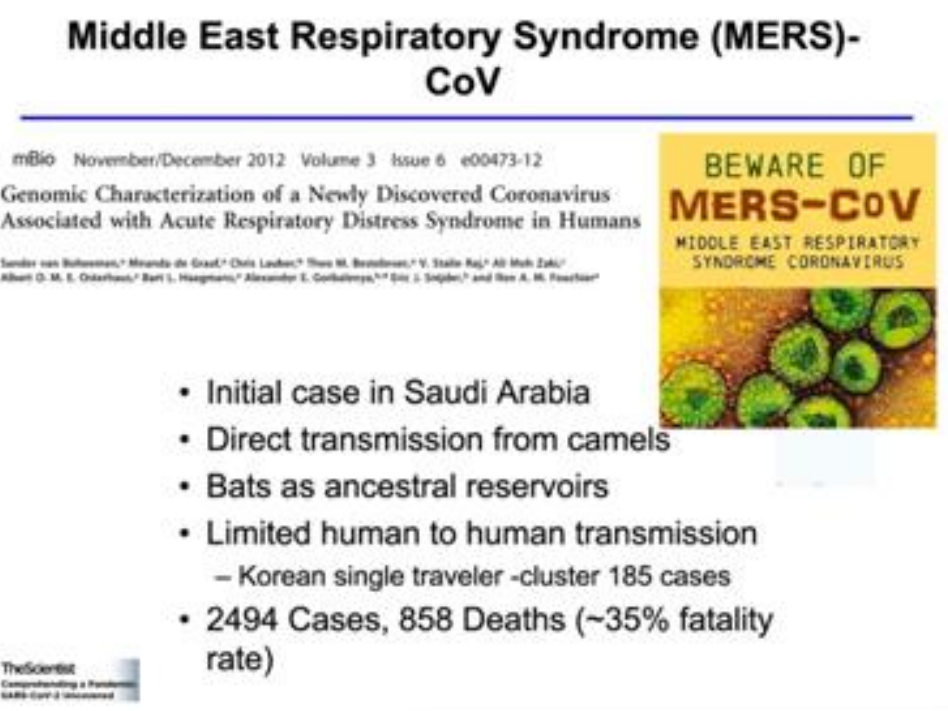

Figure4. From "Comprehending a Pandemic: SARS-CoV-2 Uncovered" https://www.the-scientist.com/sponsor ed-webinars/sars-cov-2-webinar-67527

Antibodies are the things that we try to elicit from the body during a vaccine, so one of the main ways that vaccines work against viruses is by generating antibodies that will neutralize the virus. And also, in fact, there's been interesting trials where people have taken serum from patients that have recovered from Covid-19, and given that serum to others that are very ill, and that's had a protective effect and that's because there are neutralizing antibodies in that convalescent serum, as it's called, and that can actually protect people or help them to fight the virus when they're seriously ill. 


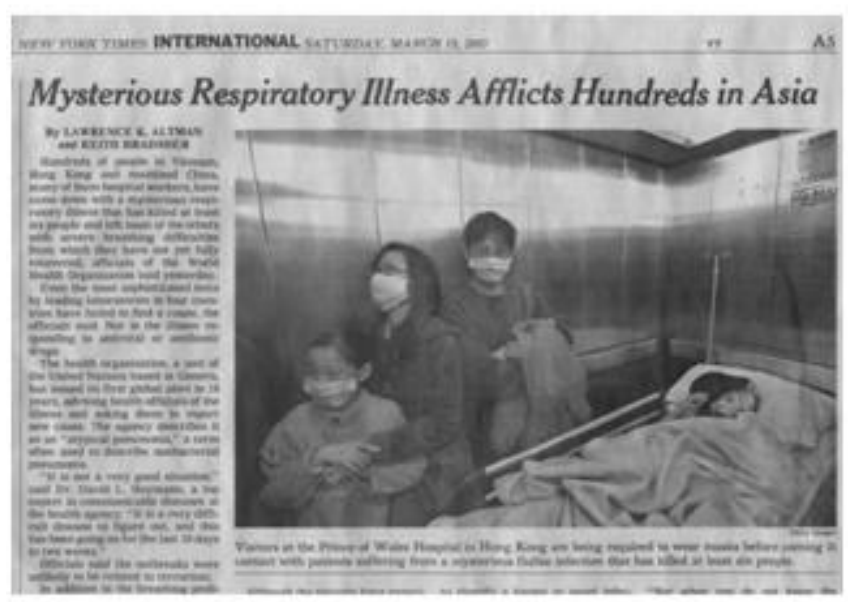

Figure5. https://www.nytimes.com/2003/03/15/world/mysterious-respiratory-illness-afflicts-hundreds-globally. html

Vaccines are different; they start as a foreign or induced agent with a safe pathogen, or maybe part of a pathogen, that isn't very dangerous to humans. Vaccines are given to try to elicit an immune response against a more dangerous, similar pathogen. A vaccine is given to someone to wake up their immune system to be able to subsequently attack the real virus or the real bacteria.

Antibodies are produced by the body to neutralize the virus. Vaccines are given to generate those antibodies.

Time - of course, it takes, typically, a good amount of time to develop a vaccine. I checked this week and there are over 130 different vaccines in development for SARS-CoV-2, so there are lots and lots of possibilities that some vaccine, hopefully, will work. But, of course, there is no guarantee. HIV has been around at least since 1910 and there is still no vaccine. So many different strategies are being tried in the hunt to develop and effective vaccine.

Computer viruses, as complex as they might at first seem to us computer users, are actually rather rudimentary compared to the biological complexities of a virus like SARS-CoV-2.

So what is a Computer Virus?

A computer virus is non-biological malicious code. It exists to spread from host to host by itself, without the user's knowledge, and to perform malicious actions. It imposes harm to a computer by corrupting system files; by manipulating, destroying or sharing data; or by affecting the computer hardware, itself. The reasons for designing computer viruses are complex, but most often, there is a form of financial exchange/reward involved in some way. Viruses can attack vulnerabilities by gaining administrative controls, at which point sensitive or confidential information is compromised, and information often shared. A computer virus tricks hardware and software, just has the SARS-Cov2 tricks our cells.

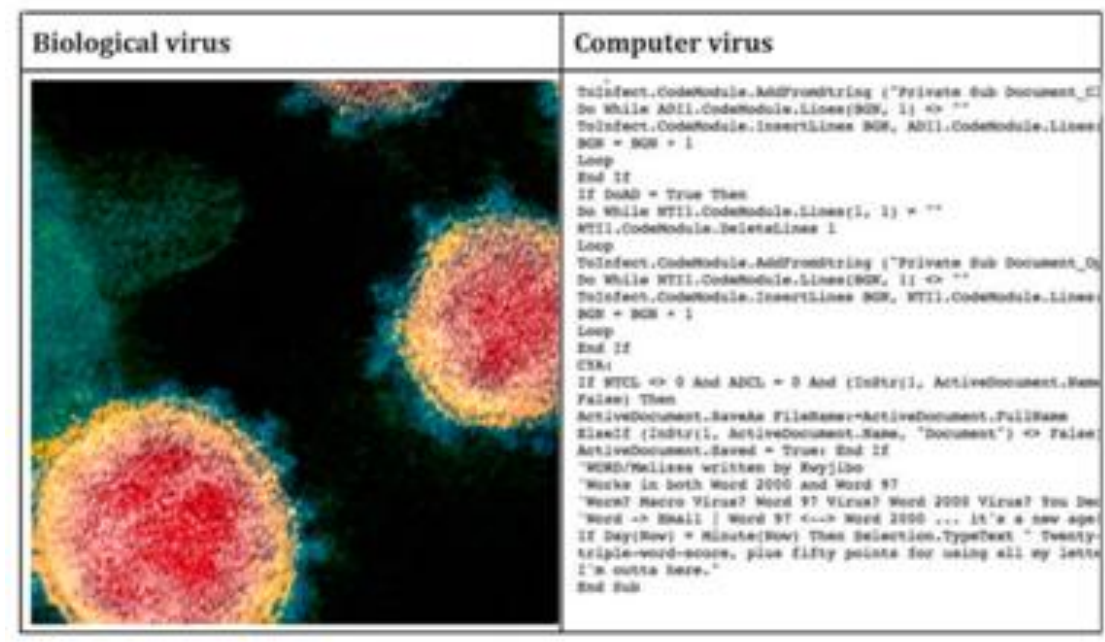


In preInternet days, a computer virus would spread through removable media. Now, save for USB sticks primarily, removable media is rare. The computer virus payload comes via internet traffic, downloads, infected files (jpg, png, gif, and mp4), and the most popular, in email attachments. In other words, a virus spreads while the user is viewing an infected file, visiting an infected website, opening the attachment in the email, or clicking on an executable file. Besides that, of course, connecting with an already infected removable storage device (such as a USB drive) also spreads the infection.

Like its biological cousin, there are primarily two ways by which a computer virus operates; the first type starts replicating itself as soon as it lands on the computer; the second type remains dormant until it is triggered. Since computers don't come with antibodies, we add those antibodies in the form of (1) antivirus, protective software and (2) robust operating systems. These two need to be loaded and updated, frequently. With protection (antivirus code), computer viruses will spread and attack systems.

Today we have to steer clear of all such malware:

- Boot Sector Virus

- Direct Action Virus

- Resident Virus

- Multipartite Virus

- Polymorphic Virus

- Overwrite Virus

- Space filler Virus

- File Infector Virus

But like our contemporary biological viruses, complex computer viruses were not always the case. In our cell-based viruses, SARS marked a significant turning point for virology in 2003. On the computer, the Michelangelo virus (so named after the famous It Renaissance painter/ sculpture/ architect/poet) was the first public malware program.

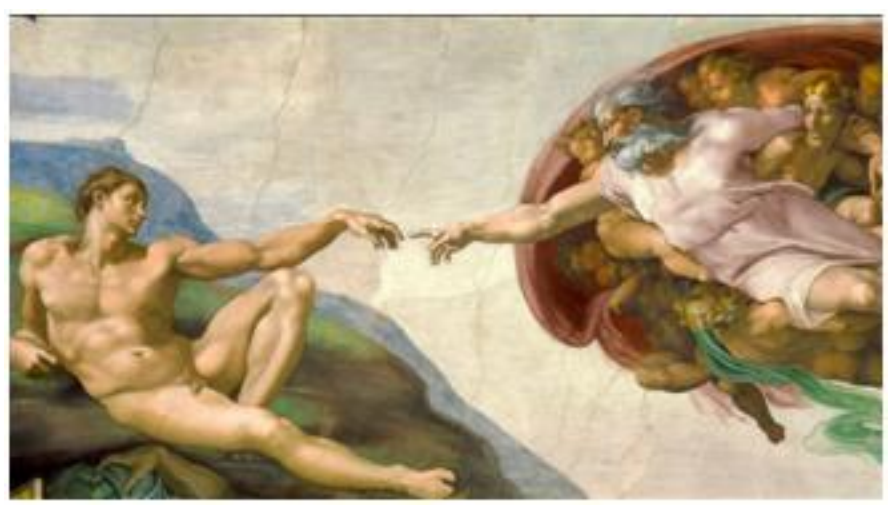

Figure6. Michelangelo's God Creating Adam from the Sistine Chapel ceiling in the Vatican, 1508-1512

It was called the Michelangelo virus because it was set to 'go off' on March 6, the traditional birth date of the Renaissance artist. By all standards a rather rudimentary piece of code, this boot sector was dormant until the specific date of March 6 . Then, any computer infected with it would have the startup sectors of its floppy disk and master book record of the hard disk totally overwritten, damaging the disk and rendering it as unusable and the data unrecoverable.

That virus also came in waves, too. The first wave was in anticipation - February 1992. I was teaching at a small college in Iowa and wrote a simple program to remove the Michelangelo virus from a floppy or hard drive. We were flooded that month with requests. I cancelled classes and my students went into production to create safe disks that would remove the Michelangelo virus, if a user's system was infected. We gave it away, gratis. There were lines of people coming out of our lab, patiently waiting for the 'fix'. We got national, even international attention at that time. And though we didn't charge for the simple fix, one of my more entrepreneurial students took an empty coffee can and 
wrote "Tips" on the side. We ate our fill of pizza for a month straight. After March 6 came and went, and the danger subsided, we all went back to our normal teaching jobs. Until November of 1992, when a variant of the Michelangelo surfaced. This was the first major hyped computer virus program.
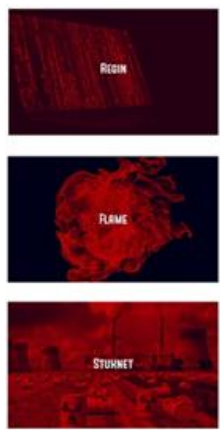
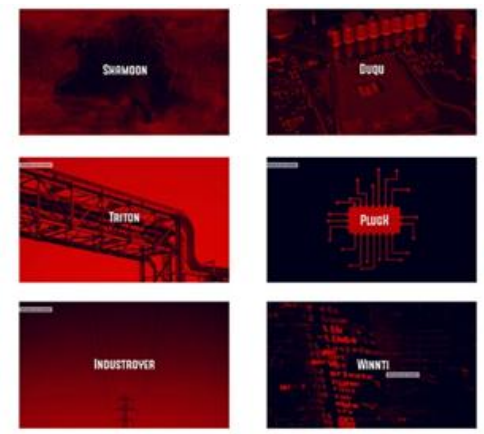
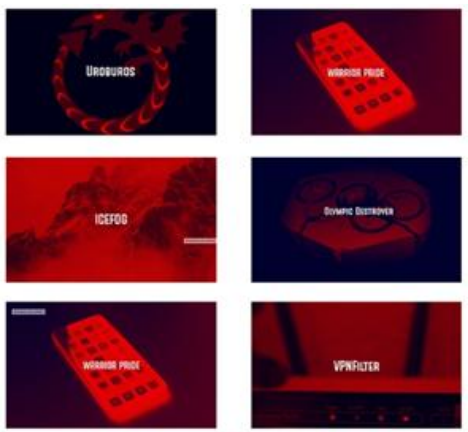
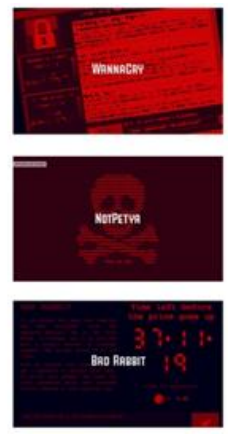

While it was estimated that over 5 million computers were probably infected (a large number 28 years ago), the actual impact was much less, about c. 20k. What the Michelangelo virus did, like the SARSCov-2 has done today, is usher in the birth and meteoric rise of various antivirus/medical vaccine companies. And while the Michelangelo virus - along with a majority of boot sector viruses - have come and gone, it retains a special place in computer info history as the first virus to bring malware awareness into the spotlight. And for many across the world, I suspect the same came be said about SARS-Cov-2. (By the way, the Michelangelo virus still activates every March 6 for older, previously infected and not cleaned computers.)

\section{Going forward}

\begin{tabular}{|l|l|l|}
\hline & Biological Virus & Computer Virus \\
\hline Parasitism & $\begin{array}{l}\text { Replicates only inside the cells of a } \\
\text { living organism using their } \\
\text { resources. }\end{array}$ & $\begin{array}{l}\text { Replicates by copying itself into } \\
\text { other computer programs. }\end{array}$ \\
\hline $\begin{array}{l}\text { Invisible } \\
\text { Phase }\end{array}$ & $\begin{array}{l}\text { Replicates inside an organism for a } \\
\text { while without any symptoms; known } \\
\text { as the incubation period. }\end{array}$ & $\begin{array}{l}\text { Can be programmed to cause harm } \\
\text { only after a certain event, such as } \\
\text { the launch of an app. }\end{array}$ \\
\hline Mutation & $\begin{array}{l}\text { Can produce copies with mutations } \\
\text { that may become resistant to } \\
\text { antibodies and drugs. }\end{array}$ & $\begin{array}{l}\text { Can change the code in its copies } \\
\text { to avoid detection by antivirus } \\
\text { software. }\end{array}$ \\
\hline $\begin{array}{l}\text { Self- } \\
\text { Defense }\end{array}$ & $\begin{array}{l}\text { Can attack and/or compromise the } \\
\text { immune system to protect itself. }\end{array}$ & $\begin{array}{l}\text { Can block antivirus software to } \\
\text { protect itself. }\end{array}$ \\
\hline
\end{tabular}

In this essay, 'virus' has been defined in two disparate ways - on one hand, biologically-based, and on the other, computer-based. At least there is a separation between the two, and we don't have to worry about computer viruses entering our biological realm.

But, no, to assume that would be wrong. As a matter of fact, in May 2020, Dr. Mark Gasson (from the Cybernetics Research Group at the University of Reading) became the first human known to be infected by a computer virus. The virus, infecting a chip implanted in Gasson's hand, was tracked from his hand to lab computers at the University. And from there, the computer infection could have spread to other computers, but did not. As you might suspect, all this was intentional, in an experiment to see how simple RFID (radio-frequency identification) chips like those used for tracking our credit cards and lorries-in-transit can host and spread technological diseases.

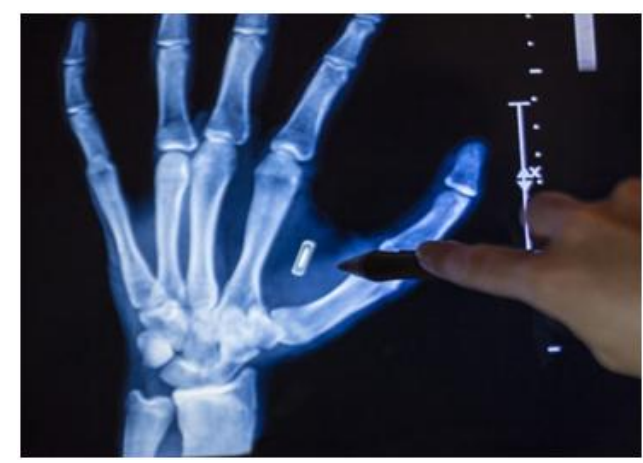

Figure7. September 4, 2019. https://www.gaia.com/article/forget-the-flu-mark-gasson-fights-infection-fromcomputer-virus 
To fight SARS-Cov-2, we take precautions (wear a mask, keep our distance and wash our hands). In the future, as Gasson and his colleagues demonstrated, a similar degree of hygiene and awareness may be necessary to keep the devices in our bodies clean as well. After all, a Denial-of-Service attack on your Mom's pacemaker could have very detrimental effects.

\section{AUTHOR'S BIOGRAPHY}

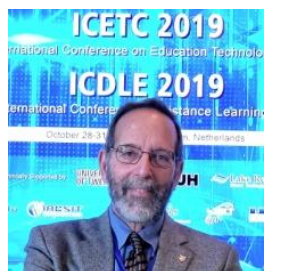

Professor Alan Garfield, is Chair of the Digital Art and Design Department at the University of Dubuque, in Dubuque, Iowa USA. He has also served as Director of the Bisignano Art Gallery since 2008. His formal education is eclectic: BA, University of Iowa; MA, State University of New York-Binghamton; Postgraduate work Wadham College, Oxford. His interests, as measured by recent publications, included 2D and 3D animation algorithms, images in contemporary politics, 19th century French philosophies, Holocaust studies, and Beat Generation poetry. He teaches in Iowa; he lives in Ireland.

Citation: Alan Garfield. "Spreading across Boundaries: Coronavirus and Computer Virus" International Journal of Humanities Social Sciences and Education (IJHSSE), vol 7, no. 12, 2020, pp. 37-44. doi: https://doi.org/10.20431/2349-0381.0712005.

Copyright: () 2020 Authors. This is an open-access article distributed under the terms of the Creative Commons Attribution License, which permits unrestricted use, distribution, and reproduction in any medium, provided the original author and source are credited. 